\title{
Determination of Radon Concentration and Annual Effective Dose Inside Houses in Left Side of Mosul City During Winter
}

\author{
Sabah Y. Hasan \\ Department of Radiology/Mosul Technical Institutes
}

(Received 19/1/2014 ; Accepted 7 / 4/2014)

\begin{abstract}
In this study, radon concentration, annual effective dose, potential alpha energy concentration (PAEC), and average of lung cancer per million persons from radon were measured using (closed can technique) containing CR-39 nuclear track detector.

Measurements were carried during winter season inside twenty four hoses in eight locations in the left side of Mosul City. The average radon concentration ranged between $(52.97 \pm 5.315$ to $74.98 \pm 5.433)$ Bq. $\mathrm{m}^{-3}$ with an average value $(62.36 \pm 7.518) \mathrm{Bq} \cdot \mathrm{m}^{-3}$ which is much lower than the recommended by ICRP action level (200-600) Bq. ${ }^{-3}$. The results showed that the potential alpha energy concentration ranged between $\left(5.71 \times 10^{-3} \pm 0.566 \times 10^{-3}\right.$ to $\left.8.11 \times 10^{-3} \pm 0.586 \times 10^{-3}\right)$ WLM with an average value $\left(6.7 \times 10^{-3} \pm 0.820 \times 10^{-3}\right) \mathrm{WLM}$, while the annual effective dose ranged between (1.34 \pm 0.134 to $1.89 \pm 0.137) \mathrm{mSvy}^{-1}$ with an average value $(1.57 \pm 0.189) \mathrm{mSvy}^{-1}$. It is observed that this value less than the recommended levels (3-10) $\mathrm{mSvy}^{-1}$ reported by ICRP. The average lung cancer cases per year per million persons were found to be $28.3 \pm 3.404$, there were no induction of existence of radon problems in this survey.
\end{abstract}

Keywords: CR-39, annual effective dose, indoor radon.

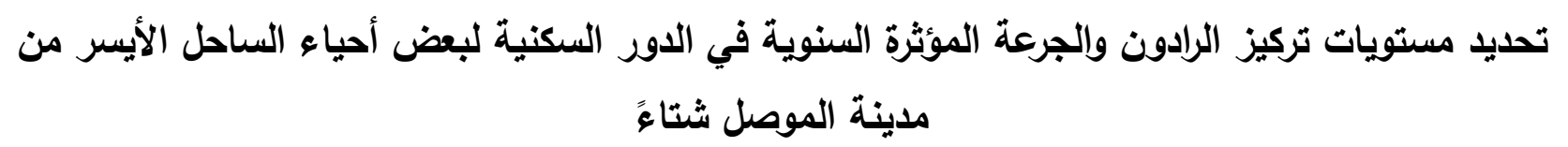

\begin{abstract}
الملخص
في هذه الدراسة تم تحديد معدل نركيز الرادون، الجرعة المؤثرة السنوية ومعدل خطر الاصـابة بسرطان الرئة لكل مليون

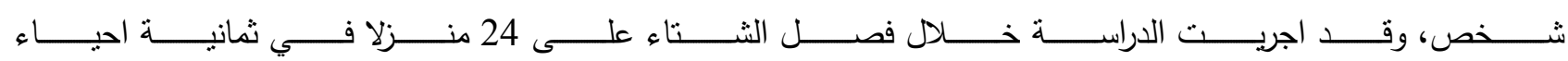

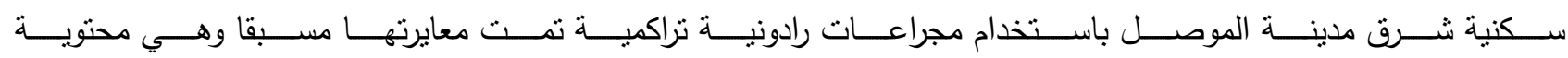
على كواثف الحالة الصلبة للمسارات النووية نوع CR-39 خلال فصل الثناء. تراوحت تراكيز الرادون بين - 52.97_5.315)

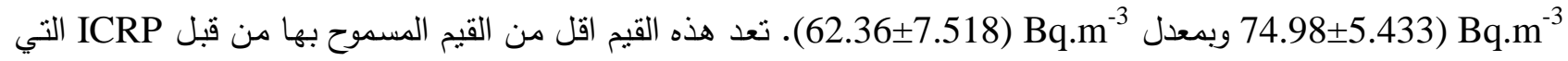

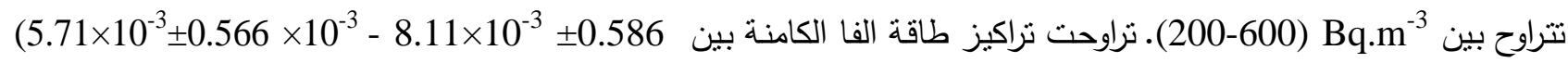
(10³ WLM

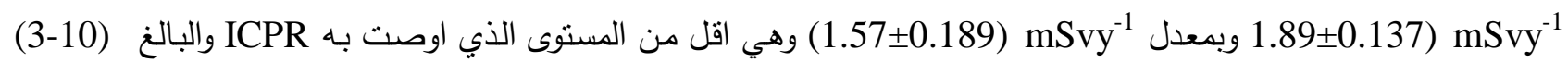
mSvy ${ }^{-1}$ هنالك خطراً للرادون في المناطق قيد الدراسة.
\end{abstract}

\section{INTRODUCTION}

Radon ${ }^{222} \mathrm{Rn}$ is naturally occuring colourless, odourless, tasteless. It is a natural radioactive decay product of ${ }^{226} \mathrm{Ra}$ an element of uranium ${ }^{238} \mathrm{U}$ decay series. Radon gas ${ }^{222} \mathrm{Rn}$ breaks down in 
eight radioactive decay steps to become stable element, lead ${ }^{206} \mathrm{~Pb}$ (Dorschel and Piesch, 1993). During this process both alpha and beta particles and gamma radiation are released. The radon and its decay products are reported as major causes of lung cancer (Abu-Haija et al., 2010).

Radon gas and its solid decay products are carcinogens. The greatest health risks come from exposure to inhaled solid radon gas decay products that are produced during the radioactive decay of radon gas. Two of these decay products ${ }^{218} \mathrm{Po}$ and ${ }^{214} \mathrm{Po}$, present a significant radiological hazard. Once the radioactive decay products are inhaled into the lung, they undergo further radioactive decay, releasing small bursts of energy in the form of alpha particles that can either causes DNA breaks or creat free radicals (Abed-Elzaher and Fahmi, 2008). The main natural sources of indoor radon are building materials (Sand, rock, cement, ....etc), tap water, natural energy sources like (gas, coal, etc.) which contain traces of ${ }^{238} \mathrm{U}$. The topography, house construction type, soil, ventilation rate, wind direction and even the life style of people (Abed-Elzaher and Fahmi, 2008), (Al-Saleh, 2007). Most of our time is spent within buildings; therefore, the measurement and limitation of radon concentration of building are important.

In the present investigation, solid state nuclear track detectors, known as passive method, are widely used for radon measurement. Radon concentrations are determined by measuring the emitted alpha particles, which causes damage in the detector surface. Because of its good ionization sensitivity and stability against various environmental condition and high degree of optical clarity, CR-39 has become the state of the art track detector for environmental radon monitoring (Danis et al., 2001). Several researchers studied indoor radon concentration levels in Iraq and other countries (Abdulla and Hussien, 2010) used solid state nuclear track detector CR-39 to study ${ }^{222} \mathrm{Rn}$ concentration in the right area of Shirkatt district in summer season. (Al-Gaim et al., 2012) used the polymer track detector LR-115 type II to measure indoor radon concentration in the dwellings and multistory buildings of Basrah technical institute (Iraq) in winter season. (Hussien et al., 2013) used CR-39 detectors to measure indoor radon concentration levels and its risks inside hospitals in Iraqi Kurdistan region in autumn season. While (Al-Jundi and Haninger, 2003) have studied the ${ }^{222} \mathrm{Rn}$ concentration in the houses of Russaifa city, Jordan by using SSNTD's (CR-39). (Al-Bataina and Elzin, 2003) also used CR-39 detectors to study the seasonal variation of indoor ${ }^{222} \mathrm{Rn}$ concentration levels in Zarqa city of Jordan. (Rassas et al., 2005) used CR-39 detectors to measure ${ }^{222} \mathrm{Rn}$ and its daughter's concentration in dwellings of Gaza strip Palestine from August to December 2001.

The main aim of this study is measure the concentration and the annual effective dose from

${ }^{222} \mathrm{Rn}$ in left side of Mosul City areas in winter season in order to measure the lung cancer risk.

\section{EXPERIMENTAL}

Passive radon dosimeter containing solid state nuclear track detectors (SSNTD's), CR-39, was used in this work. The schematic diagram of the dosimeter is shown elsewhere (Abumurad et al., 1994) and composed of plastic cup $7.0 \mathrm{~cm}$ in diameter and $4.6 \mathrm{~cm}$ in depth. A circular hole of radius $0.75 \mathrm{~cm}$ was made at the center of the Lid. The hole is covered by a piece of sponge with an area of $2 \mathrm{~cm} \times 2 \mathrm{~cm}$ and thickness $0.5 \mathrm{~cm}$, this configuration was used in order to maintain the same calibration conditions and to stop aerosol and thoron ${ }^{220} \mathrm{Rn}$ from entering the cup and only radon ${ }^{222} \mathrm{Rn}$ diffuses into the sensitive volume of dosimeter. Plastic contains one piece of CR-39 with area $1 \times 1 \mathrm{~cm}^{2}$ fixed to the bottom of the cup using a scotch tape, the calibration process for this dosimeters was done by (Al-Kofahi et al., 1992). After preparing the dosimeter, they were distributed into the houses of eight different areas of left side of Mosul city. These locations are, Al-Kafaat/2, Al-Hadba, Al-Baladyat, Al-Massaref, Al-Tahreer, AlZahraa, Al-Noor and Nenavah-al-Sharqiya. We chose three houses in each location randomly, one dosimeter were hung in the ceiling inside each selected house, in living room on the top about $2 \mathrm{~m}$ above the floor. The rooms under study were built, in general, using cement, sand, iron structure, blocks and concrete as the construction materials. The walls of the dwellings are often covered with 
gypson, most of the rooms are of sizes approximately $4 \times 4 \times 3 \mathrm{~m}^{3}$ with one window and one door. The measurement were performed for a period of two months (27/12/2010-25/2/2011).

The detectors were collected after 60 days and chemically etched using $6.25 \mathrm{~N}$ solution $\mathrm{NaOH}$ at $70 \pm 1{ }^{\circ} \mathrm{C}$ for $4 \mathrm{hrs}$.

After etching process taking, the detectors were washed for $30 \mathrm{~min} .$, by running water, then by distilling water and then drying out.

Track densities were counted by using an optical microscope with magnification of 400X. the correction was applied for the background alpha tracks in CR-39 plastic by subtracting the number of tracks observed in the unexposed detector. The average concentration of radon gas was determined by using the relation (Al-Bataina and Elzain, 2003).

$$
\mathbf{C}=\frac{\mathbf{C}_{0} \mathbf{t}_{0} \rho}{\mathbf{t}_{\rho_{0}}}
$$

Where $C_{0}$ is radon concentration of calibrated champer $\left(90 \mathrm{kBq} \cdot \mathrm{m}^{-3}\right), \mathrm{t}_{0}$ is the calibration exposure time (48 hours), $\rho$ is the measured track number density per $\mathrm{cm}^{2}$ on the CR-39 detectors inside the dosimeters used in the study, $\rho_{0}$ is the measured track number density per $\mathrm{cm}^{2}$ on the detectors of the calibrated dosimeters which is equal $96768{\mathrm{Tr} . \mathrm{cm}^{-2}}^{-}$and $\mathrm{t}$ is the indoor exposure time for the survey.

To find the potential alpha energy concentration (PAEC) of ${ }^{222} \mathrm{Rn}$ in term of working level WL first of all we found the concentration of radon in $\mathrm{PCiL}^{-1}$ units, so the equivalent equilibrium concentration EEC of radon deduce as in equ. (Abdulla and Hussein, 2010).

$$
\mathrm{EEC}=\mathrm{FxC}_{\mathrm{Rn}}\left(\mathrm{PCiL}^{-1}\right)
$$

Were $\mathrm{F}$ is the equilibrium factor, which equal to 0.4 indoor. Then EEC times 0.01 to find PAEC (WLM), while $\mathrm{WLMY}^{-1}$ is equivalent to WL times factor 40 (Abdulla and Hussein, 2010).

The effective dose from ${ }^{222} \mathrm{Rn}$ progeny $\mathrm{H}\left(\mathrm{mSvy}^{-1}\right)$ was calculated from the following formula according to (UNSCAR, 2000), (Al-Saleh, 2007).

$$
\mathrm{H}_{\mathrm{E}}=\mathrm{C} \times \mathrm{F} \times \mathrm{O} \times \mathrm{T} \times \mathrm{D}
$$

Where $\mathrm{C}$ is the radon concentration in Bq. $\mathrm{m}^{-3}, \mathrm{~F}$ equilibrium factor 0.4 indoor, $\mathrm{O}$ occupancy factor 0.8 , T time $8760 \mathrm{hy}^{-1}$ and $\mathrm{D}$ dose conversion factor $9 \times 10^{-6} \mathrm{~m} \mathrm{Svh}^{-1} / \mathrm{Bq} \cdot \mathrm{m}^{-3}$. While the Lung cancer cases per year per million persons based on the risk factor lung cancer induction of $18 \times 10^{-6}$ $\mathrm{mSvy}^{-1}$ (Mansur et al., 2005).

\section{RESULTS AND DISCUSSION}

Table (1) shows that the indoor radon concentration measured in living rooms of twenty four different houses in left side of Mosul city. The data showed that the minimum radon concentration was in Al-Kafaat/2 house No. 21 (49.006) Bq. ${ }^{-3}$ which is very near to radon concentration in house No. 14 (49.7) Bq. $\mathrm{m}^{-3}$ in Al-Tahreer location, while the maximum radon concentration found in house No. 7 (81.23) Bq.m ${ }^{-3}$ in Al-Masaref location. Houses $(4,8,9,11)$ approximately having the same radon concentrations. The average radon concentration ranged between $(52.97 \pm 5.315$ to $74.98 \pm 5.433) \mathrm{Bq} \cdot \mathrm{m}^{-3}$ in Al-Tahreer and Al-Masaref locations respectively. The average radon concentration in all locations was $(62.36 \pm 7.518) \mathrm{Bq} \cdot \mathrm{m}^{-3}$, which is much lower than the recommended by ICRP action level of (200-600) Bq. $\mathrm{m}^{-3}$ (ICRP, 1993).

The variation in radon concentration values inside locations under study is mainly due to geological characteristics of the soil, building materials, climate, also poor ventilation rate plays an 
important role of radon concentration, because people often close their doors and windows for warmth during winter, this will increase of radon concentration. When comparing the present results with others obtained by (Stojanovask et al., 2011) studied indoor radon concentration in FYR of Macedonia results showed that the average radon concentration was $115 \mathrm{~Bq} \cdot \mathrm{m}^{-3}$ in winter season. (Al-Jundi and Haninger, 2003) measured indoor radon concentration levels in Zarqa city of Jordan, results indicated that radon concentration ranged from (81 to 294) Bq. $\mathrm{m}^{-3}$ in winter season. (Abdulla and Husain, 2010) found an average radon concentration (103.98) Bq. $\mathrm{m}^{-3}$ on his study for radon concentration in Shirkatt district in summer season. Also (Najeba and Mohamad, 2012) found an average radon concentration $187.215 \mathrm{~Bq} . \mathrm{m}^{-3}$ on their study for radon concentration in 30 spatial dwellings in three governorates in Iraqi Kurdistan. These researches revealed that our result for radon concentration is lower. However the present results were similar to those obtained by (Guo et al., 2001) on his survey for indoor radon and thoron and it's progeny in four areas in China which is equal to $61.2 \mathrm{~Bq} \cdot \mathrm{m}^{-3}$ in winter season, while our results are higher than that obtained by (Buzkurt and Kam, 2007) which it was 49.2 Bq.m ${ }^{-3}$ in the city of Edirne, Turky, also (Al-Gaim et al., 2012) found that radon concentration ranged from (13.52 to 51.17) Bq.m ${ }^{-3}$ in the dwellings and multistory buildings of Basrah Technical institute (Iraq) in winter season.

Table 1: Indoor radon concentration in the left side of Mosul city

\begin{tabular}{|c|c|c|c|c|c|}
\hline Location & Houses No. & $\mathrm{C}_{\mathrm{Rn}}\left(\mathrm{Bq} \cdot \mathrm{m}^{-3}\right)$ & $\begin{array}{c}\text { Average } \pm \text { S.D. } \\
C_{R n}\left(B q \cdot m^{-3}\right)\end{array}$ & $\mathrm{C}(\mathbf{p c i} / \mathbf{L})$ & $\begin{array}{c}\text { Average } \pm \text { S.D. } \\
\text { C(pci/L) }\end{array}$ \\
\hline \multirow{3}{*}{$\begin{array}{l}\text { Nenavah } \\
\text { Al-Sharqiya }\end{array}$} & 1 & 65.3 & \multirow{3}{*}{$\begin{array}{l}60.94 \\
\pm 4.43\end{array}$} & 1.745 & \multirow{3}{*}{$\begin{array}{c}1.64 \\
\pm 0.11\end{array}$} \\
\hline & 2 & 61.1 & & 1.651 & \\
\hline & 3 & 56.44 & & 1.525 & \\
\hline \multirow{3}{*}{ Al-Noor } & 4 & 70.5 & \multirow{3}{*}{$\begin{array}{c}65.99 \\
\pm 4.613\end{array}$} & 1.905 & \multirow{3}{*}{$\begin{array}{c}1.78 \\
\pm 0.124\end{array}$} \\
\hline & 5 & 66.2 & & 1.789 & \\
\hline & 6 & 61.28 & & 1.656 & \\
\hline \multirow{3}{*}{ Al-Masaref } & 7 & 81.23 & \multirow{3}{*}{$\begin{array}{c}74.98 \\
\pm 5.433\end{array}$} & 2.195 & \multirow{3}{*}{$\begin{array}{c}2.02 \\
\pm 0.146\end{array}$} \\
\hline & 8 & 72.4 & & 1.957 & \\
\hline & 9 & 71.33 & & 1.928 & \\
\hline \multirow{3}{*}{ Al-Baladyat } & 10 & 74 & \multirow{3}{*}{$\begin{array}{c}68.98 \\
\pm 5.923\end{array}$} & 2 & \multirow{3}{*}{$\begin{array}{c}1.86 \\
\pm 0.159\end{array}$} \\
\hline & 11 & 70.51 & & 1.91 & \\
\hline & 12 & 62.45 & & 1.69 & \\
\hline \multirow{3}{*}{ Al-Tahreer } & 13 & 50.12 & \multirow{3}{*}{$\begin{array}{c}52.97 \\
\pm 5.315\end{array}$} & 1.35 & \multirow{3}{*}{$\begin{array}{c}1.43 \\
\pm 0.141\end{array}$} \\
\hline & 14 & 49.7 & & 1.34 & \\
\hline & 15 & 59.11 & & 1.59 & \\
\hline \multirow{3}{*}{ Al-Zahraa } & 16 & 63.003 & \multirow{3}{*}{$\begin{array}{l}58.001 \\
\pm 4.584\end{array}$} & 1.7 & \multirow{3}{*}{$\begin{array}{c}1.56 \\
\pm 0.122\end{array}$} \\
\hline & 17 & 57 & & 1.54 & \\
\hline & 18 & 54 & & 1.46 & \\
\hline \multirow{3}{*}{ Al-Kafaat/2 } & 19 & 60 & \multirow{3}{*}{$\begin{array}{l}54.002 \\
\pm 5.565\end{array}$} & 1.62 & \multirow{3}{*}{$\begin{array}{c}1.45 \\
\pm 0.151\end{array}$} \\
\hline & 20 & 53 & & 1.43 & \\
\hline & 21 & 49.006 & & 1.32 & \\
\hline \multirow{3}{*}{ Al-Hadba } & 22 & 65.1 & \multirow{3}{*}{$\begin{array}{c}62.99 \\
\pm 2.993\end{array}$} & 1.759 & \multirow{3}{*}{$\begin{array}{c}1.70 \\
\pm 0.079\end{array}$} \\
\hline & 23 & 64.23 & & 1.736 & \\
\hline & 24 & 59.64 & & 1.612 & \\
\hline Average \pm S.D. & & $62.36 \pm 8.250$ & $62.36 \pm 7.518$ & $1.68 \pm 0.224$ & $1.68 \pm 0.203$ \\
\hline
\end{tabular}

Table (2) shows that the potential alpha energy ranged between $5.28 \times 10^{-3}$ WLM in house No. 21 in Al-Kafaat/2 location and $8.78 \times 10^{-3}$ WLM in house No. 7 in Al-Masaref location, while the average PAEC ranged between $\left(5.71 \times 10^{-3} \pm 0.566 \times 10^{-3}\right.$ to $\left.8.11 \times 10^{-3} \pm 0.586 \times 10^{-3}\right)$ WLM in AlTahreer and Al-Masaref location respectively. The average for all locations was $\left(6.7 \times 10^{-3} \pm\right.$ $\left.0.820 \times 10^{-3}\right)$ WLM. 
Table 2: Summarized the measurement of EEC, PAEC, WLMY ${ }^{-1}$

\begin{tabular}{|c|c|c|c|c|c|}
\hline Location & House No. & EEC & $\begin{array}{c}\text { PAEC } \\
(\text { WLM) } \\
\times \mathbf{1 0}^{-3}\end{array}$ & $\begin{array}{c}\text { Average PAEC } \\
\pm \text { S.D. } \\
(\text { WLM) } \\
\times \mathbf{1 0}^{-3} \\
\end{array}$ & $\mathbf{W L M Y}^{-1}$ \\
\hline \multirow{3}{*}{$\begin{array}{l}\text { Nenavah } \\
\text { Al-Sharqiya }\end{array}$} & 1 & 0.698 & 6.98 & \multirow{3}{*}{$\begin{array}{c}6.56 \\
\pm 0.441\end{array}$} & 0.279 \\
\hline & 2 & 0.660 & 6.6 & & 0.264 \\
\hline & 3 & 0.61 & 6.1 & & 0.244 \\
\hline \multirow{3}{*}{ Al-Noor } & 4 & 0.762 & 7.62 & \multirow{3}{*}{$\begin{array}{l}7.13 \\
\pm 0.5\end{array}$} & 0.305 \\
\hline & 5 & 0.716 & 7.16 & & 0.286 \\
\hline & 6 & 0.662 & 6.62 & & 0.265 \\
\hline \multirow{3}{*}{ Al-Masaref } & 7 & 0.878 & 8.78 & \multirow{3}{*}{$\begin{array}{c}8.11 \\
\pm 0.586\end{array}$} & 0.351 \\
\hline & 8 & 0.783 & 7.83 & & 0.313 \\
\hline & 9 & 0.771 & 7.71 & & 0.308 \\
\hline \multirow{3}{*}{ Al-Baladyat } & 10 & 0.8 & 8 & \multirow{3}{*}{$\begin{array}{c}7.47 \\
\pm 0.637\end{array}$} & 0.32 \\
\hline & 11 & 0.764 & 7.64 & & 0.305 \\
\hline & 12 & 0.676 & 6.76 & & 0.27 \\
\hline \multirow{3}{*}{ Al-Tahreer } & 13 & 0.54 & 5.4 & \multirow{3}{*}{$\begin{array}{c}5.71 \\
\pm 0.566\end{array}$} & 0.216 \\
\hline & 14 & 0.536 & 5.36 & & 0.214 \\
\hline & 15 & 0.636 & 6.36 & & 0.254 \\
\hline \multirow{3}{*}{ Al-Zahraa } & 16 & 0.68 & 6.8 & \multirow{3}{*}{$\begin{array}{c}6.27 \\
\pm 0.488\end{array}$} & 0.272 \\
\hline & 17 & 0.616 & 6.16 & & 0.246 \\
\hline & 18 & 0.584 & 5.84 & & 0.234 \\
\hline \multirow{3}{*}{ Al-Kafaat/2 } & 19 & 0.648 & 6.48 & \multirow{3}{*}{$\begin{array}{c}5.83 \\
\pm 0.625\end{array}$} & 0.259 \\
\hline & 20 & 0.572 & 5.72 & & 0.228 \\
\hline & 21 & 0.528 & 5.28 & & 0.211 \\
\hline \multirow{3}{*}{ Al-Hadba } & 22 & 0.703 & 7.03 & \multirow{3}{*}{$\begin{array}{c}6.81 \\
\pm 0.312\end{array}$} & 0.281 \\
\hline & 23 & 0.694 & 6.94 & & 0.277 \\
\hline & 24 & 0.645 & 6.45 & & 0.258 \\
\hline Average & & & $6.7 \pm 0.898$ & $6.7 \pm 0.820$ & $0.269 \pm 0.0359$ \\
\hline
\end{tabular}

Table (3) shows the annual effective dose ranged between $1.236 \mathrm{mSvy}^{-1}$ in house No.21 in Al-Kafaat/2 and $2.049 \mathrm{mSvy}^{-1}$ in house No. 7 in Al-Masaref location with an average value for all locations $(1.57 \pm 0.189) \mathrm{mSvy}^{-1}$. In the present survey the annual effective dose received by the resident less than the range of action level (3-10) $\mathrm{mSvy}^{-1}$ recommended by (ICRP, 1993).

Table (3) also shows that radon induced lung cancer risk for all houses in left side of Mosul city was found and ranges from $(24.1 \pm 2.415)$ per million persons to $(34.02 \pm 2.483)$ per million persons with an average value of $28.3 \pm 3.404$ per million persons.

In general, these results indicate that the houses in left side of Mosul city are characterized by low radon exposure dose, so the people who live in those houses are subject to relatively low risk factor for radon induced lung cancer. 
Table 3 : Annual effective dose $\left(\mathrm{mSvy}^{-1}\right)$ and risk assessment per million persons

\begin{tabular}{|c|c|c|c|c|c|}
\hline Location & House No. & $\mathrm{mSvy}^{-1}$ & $\begin{array}{c}\text { Average } \\
\pm \text { S.D. mSvy }\end{array}$ & $\begin{array}{c}\text { Risk } \\
\text { Assessment per } \\
10^{6} \text { person }\end{array}$ & $\begin{array}{c}\text { Average Risk } \\
\text { Assessment } \\
\pm \text { S.D. } \\
\text { per } 10^{6} \text { person }\end{array}$ \\
\hline \multirow{3}{*}{$\begin{array}{c}\text { Nenavah } \\
\text { Al-Sharqiya }\end{array}$} & 1 & 1.647 & \multirow{3}{*}{$\begin{array}{c}1.54 \\
\pm 0.111\end{array}$} & 29.65 & \multirow{3}{*}{$\begin{array}{c}27.7 \\
\pm 2.01\end{array}$} \\
\hline & 2 & 1.541 & & 27.74 & \\
\hline & 3 & 1.424 & & 25.63 & \\
\hline \multirow{3}{*}{ Al-Noor } & 4 & 1.778 & \multirow{3}{*}{$\begin{array}{c}1.67 \\
\pm 0.116\end{array}$} & 32.004 & \multirow{3}{*}{$\begin{array}{c}29.96 \\
\pm 2.088\end{array}$} \\
\hline & 5 & 1.67 & & 30.06 & \\
\hline & 6 & 1.546 & & 27.83 & \\
\hline \multirow{3}{*}{ Al-Masaref } & 7 & 2.049 & \multirow{3}{*}{$\begin{array}{c}1.89 \\
\pm 0.137\end{array}$} & 36.88 & \multirow{3}{*}{$\begin{array}{c}34.02 \\
\pm 2.483\end{array}$} \\
\hline & 8 & 1.823 & & 32.81 & \\
\hline & 9 & 1.799 & & 32.38 & \\
\hline \multirow{3}{*}{ Al-Baladyat } & 10 & 1.867 & \multirow{3}{*}{$\begin{array}{c}1.74 \\
\pm 0.147\end{array}$} & 33.6 & \multirow{3}{*}{$\begin{array}{c}31.32 \\
\pm 2.687\end{array}$} \\
\hline & 11 & 1.779 & & 32.02 & \\
\hline & 12 & 1.576 & & 28.36 & \\
\hline \multirow{3}{*}{ Al-Tahreer } & 13 & 1.264 & \multirow{3}{*}{$\begin{array}{c}1.34 \\
\pm 0.134\end{array}$} & 22.75 & \multirow{3}{*}{$\begin{array}{c}24.1 \\
\pm 2.415\end{array}$} \\
\hline & 14 & 1.254 & & 22.57 & \\
\hline & 15 & 1.491 & & 26.84 & \\
\hline \multirow{3}{*}{ Al-Zahraa } & 16 & 1.589 & \multirow{3}{*}{$\begin{array}{c}1.46 \\
\pm 0.155\end{array}$} & 28.6 & \multirow{3}{*}{$\begin{array}{c}26.3 \\
\pm 2.077\end{array}$} \\
\hline & 17 & 1.438 & & 25.88 & \\
\hline & 18 & 1.362 & & 24.52 & \\
\hline \multirow{3}{*}{ Al-Kafaat/2 } & 19 & 1.514 & \multirow{3}{*}{$\begin{array}{c}1.36 \\
\pm 0.14\end{array}$} & 27.25 & \multirow{3}{*}{$\begin{array}{c}24.5 \\
\pm 2.536\end{array}$} \\
\hline & 20 & 1.337 & & 24.06 & \\
\hline & 21 & 1.236 & & 22.24 & \\
\hline \multirow{3}{*}{ Al-Hadba } & 22 & 1.642 & \multirow{3}{*}{$\begin{array}{c}1.59 \\
\pm 0.073\end{array}$} & 29.55 & \multirow{3}{*}{$\begin{array}{c}28.6 \\
\pm 1.322\end{array}$} \\
\hline & 23 & 1.62 & & 29.16 & \\
\hline & 24 & 1.505 & & 27.09 & \\
\hline Average & & $1.57 \pm 0.208$ & $1.57 \pm 0.189$ & $28.3 \pm 3.755$ & $28.3 \pm 3.404$ \\
\hline
\end{tabular}

\section{CONCLUSION}

It has been found that the average radon concentration level in left side of Mosul city was $(62.36 \pm 7.518)$ Bq.m ${ }^{-3}$ in winter season which is below radon reference levels ranged from (200 to 600) Bq.m ${ }^{-3}$ as recommended by ICRP, furthermore the average annual effective dose equivalent due to indoor radon was $(1.57 \pm 0.189) \mathrm{m} \mathrm{Svy}^{-1}$ which is less than the range of action level (3-10) $\mathrm{m} \mathrm{Svy}^{-1}$ recommended by ICRP.

\section{REFERENCES}

Abdulla, A.A.; Hussien, H.I. (2010). Study of radon concentration and lung cancer risk in the right area of Shirkatt district. J. Anbar Univ. for Pure Sci., 4(1),60-64.

Abed- Elzaher, M.; Fahmi, N.M. (2008). Studying the variation of radon level in some houses in Alexandria city, Egypt. 1X Rad. Phy. and Prot. Conf. 15-19 November 339-347.

Abu-Haija, O.; Salameh, B.; Ajlouni, A.W.; Abedelsalam, M.; Ebaisat, H. (2010). Measurement of radon concentration inside houses in Tafila province, Jordan. Inter. J. the Phys. Sci., 5(6), 696-699.

Abumurad, K.M.; Kullab, M.K.; Al-Bataina, B.A.; Ismail, A.M.; Lehlooh, A.D. (1994). Estimation of radon concentration inside houses in some Jordanian region. Mu'tah J. for Resc. and Studi., 9(5),9-20.

Al-Bataina, B.A.; El-Zain, A.A. (2003). Seasonal variation of indoor radon-222 concentration levels in Zarka city of Jordan. Abhath Al-Yarmouk. Basic Sci. and Eng., 12(1),191-202. 
Al-Gaim, H.R.M.; Al-Khalifa, I.J.M.; Al-Helal, M.A.A. (2012). Indoor radon measurements in the dwellings and multistory buildings of Basrah Technical Institute (Iraq). J. Basrah Reser. Sci., 38(1A), 8-13.

Al-Jundi, J.; Haninger, T. (2003). Radon-222 concentration in the houses of Russafi city Jordan. Ahath Al-Yarmouk Basic Sci. and Eng., 12(1),181-190.

Al-Kofahi, M.M.; Khader, B.R.; Lehlooh, A.D.; Kulab, M.K. (1992). Measurement of radon-222 in jordanian dwelling. Nucl. Tracks. Radiat. Meas., 20,377-382.

Al-Saleh, F.S. (2007). Measurement of indoor gamma radiation and radon concentration in dwellings of Riyadh city, Saudi Arabia. Appl. Radiat. And Isotopes., 65,843-848.

Bozkurt, A.; Kam, E. (2007). indoor radon measurement in the city of Edirne Turky. Sixth international conference of the Balkan physical union.

Danis, A.; Oncescu, M.; Ciubotariu, (2001). System for calibration of track detectors use in gaseous and solid alpha radionuclides monitoring. Radiat. Meas., 34,155-159.

Dorschel, B.; Piesch, E. (1993). A new approach to estimating the equilibrium factor between radon and its daughters. Radiat. Protec. Dosim., 48(2),145-151.

Guo, Q.; Cheng, J.; Sun, J. (2001). The levels of indoor thoron an it's progeny in four Areas of China. J. Nucl. Sci. and Techno., 38(9),799-803.

Hussein, Z.A.; Jaafer, M.S.; Ismail, A.H.(2013). Measurement of indoor radon concentration levels and its risks inside hospitals in iraqi kurdistan region: case study in autumn season. J. Phys. and Envi. Sci. Res., 2(1),1-6.

ICRP (1993). International commission on radiological protection against radon-222 at home and work. ICRP report 65.Ann. ICRP, Pergamon Press, Oxford.

Mansur, H.H.; Khadar, S.; Abdulla, H.Y.; Mohamad, N.Q.; Othman, M.M.; Qader, S. (2005). Measurement of indoor radon level in Erbil capital by using solid state nuclear track detector. Radiat. Meas., 40,544-547.

Najeba, F.S.; Mohamad, S.J. (2012). Assessment of indoor radon concentration in dwelligns in iraqi kurdistan using CR-39 dosimeters. Healt and Enviro. J., 3(3),23-27.

Rassas, M.F.; Yassin, S.S.; Shbat, M.M. (2005). Measurement of radon-222 and daughter's concentrations in dwellings of Gaza strip, Palestine. J. Islamic Univ. of Gaza (Natural Science Series). 13(2), 9-18.

Stojanovask, Z.; Januseski, J.; Bossewl, P.; Zunic, Z.S.; Tollefsen, T.; Restova, M. (2011). Seasonal indoor radon concentration in FYR Macedonia. J. Radia. Meas. 46,602-610. 